\title{
The Contribution of the Internal Audit Function in Risk Management
}

\author{
Dr. Faten Hanna Kerazan
}

Accounting Dept, University of Jordan

\author{
Received: Feb 24, 2016 \\ Accepted: May 17, 2016 Published: July 1, 2016 \\ doi:10.5296/jmr.v8i3.9096 \\ URL: http://dx.doi.org/10.5296/jmr.v8i3.9096
}

\begin{abstract}
This study aimed to identify the contribution of internal audit in risk management in Syrian public and private banks, the questionnaire was used in collecting the initial data, which was distributed to a sample of board of directors and executives in these banks.

The study found that there is a contribution to the internal audit function in risk management in all Syrian public and private banks and there are no statistically significant differences on this contribution.

The study recommended of the need to conduct training courses for workers in the internal audit function and issue instructions and necessary legislations to regulate the activity of internal audit in banks, a committee of internal audit must be formed within the Association of Chartered Accountants in Syria, where its mission is to the development of internal auditors and the need for cooperation of professional organizations of accounting, auditing and regulatory bodies in Syria to establish an association for internal auditors to qualify them and give them a professional certification to carry out their roles under the new framework for exercising of the profession that guarantees to provide the necessary advice and guidance for them to bring the profession up to the required level.
\end{abstract}

Keywords: internal audit, risk management, Syrian public and private banks, function 


\section{Introduction}

Economic activity environment is always characterized by the presence of risks that threaten the possibility of the entity to achieve its objectives, as the risk is also representing one of the most important determinants of success in this environment, where the entity management confronts the entity's assets for risk in order to achieve the activity objectives, regardless of the form of entity whether it was (profit/ non-profit), so the function of it is to achieve the goals of the entity in an environment of uncertainty and risk-filled, and so the management term becomes synonymous with risk management (McNamee: 2000)

The risk management is an important and vital activity exercised by the administration based on the contributions of all the units and administrative functions within the entity to control those risks, audit activity and internal control are relevant to risk management and there is a strong link between the internal audit function and the level of commitment to risk management, and the more the entity will be committed and willing to risk management, the more is the need for the use of the internal audit function (Goodwin: 2006), and from the recent trends in practice, the emergence of the so-called risk-based audit.

\section{Research Problem}

The evolution in the internal audit function included activities beyond the traditional tasks carried out by units of internal audit in entities, so it included the attempt to control the risk in the lower and accepted limits, which summoned to study the reality of the contribution of internal audit in risk management in line with the role of the developer of the function of internal audit especially in the banking sector that the nature of their work exposed to a high degree of risk and diverse problem of the study can be determined in the following questions:

1. Does the Internal Audit contribute in risk management in public Syrian banks?

2. Does Internal Audit contribute in risk management in private Syrian banks?

3. Are there statistically significant differences between the contributions of internal audit in the risk management between private or public banks sector.

\section{Significanc of the Research}

- Recognition of the internal audit contribution in the success of risk management in banks will highlight the importance of adopting an active role of internal audit which is supported by senior management to enable the banks to keep risks in the acceptable minimum and controlled limits.

- Improve the perception of the internal audit by the departments in Syrian banks by not confined to traditional control function, but it became prudent and precautionary function that contributes in maintaining the bank assets and raises its efficiency.

- Come up with recommendations that contribute to the improvement of risk management in banks through strengthening the internal audit function, increase the confidence and reduce risk in credit granting decisions, through the development of controls that could be imposed when making those decisions. 
Internal Auditors Institute in the United Kingdom sees that there is a new request reflects a significant change in the spirit and practice of internal audit of its focus on the financial side to the attention of a broad analysis of critical business risks (Al-Kabbani, Thana' Ali: 2006).

The internal audit function became a part of the traditional responsibilities of the internal auditor, therefore internal auditors must expand to the services provided to the management (Mclemore: 1999).

Thus, the significance of this research stems from the importance of Internal Audit and the developments in the profession to this day in line with the expansion of the needs of the administration and its demands, as well as the importance of risk management in general and banking risks, in particular, this importance stems from the active role of the Syrian banking sector and its impact on the national economy.

\section{Research Objectives}

1. Recognize the contribution of Internal Audit in risk management in Syrian public banks.

2. Recognize the contribution of Internal Audit in risk management in Syrian private banks.

3. Identify whether there are statistically significant differences between the contributions of internal audit in risk management between private or public banks sector.

\section{Research Hypotheses}

To achieve the objectives of the research, its hypotheses can be formulated as follows:

\section{First Hypothesis}

H0: Internal Audit does not contribute in risk management in Syrian public banks.

\section{Second Hypothesis}

H0: Internal Audit does not contribute in risk management in Syrian public or private banks.

\section{Third Hypothesis}

H0: There are no statistically significant differences between the contributions of internal audit in risk management between private or public banks sector.

\section{Theoretical Framework and Previous Studies}

There were many attempts to develop a suggested approach for the development of the role of internal audit based on risk as an important tool for banking risks management within the framework of the implementation of the requirements of the Basel Committee through defining the core banking risks and determine their types and highlight the importance of internal audit within the governance framework in general and in the banking governance framework in particular and to clarify the role of the integration of the balanced performance model and the entity risk management model to achieve the effectiveness of the internal audit based on risks of controlling bank risks. It shows that the effective application of risk management in businesses in general and banks in particular to ensure the achievement of the 
strategic objectives of achieving stability and growth and expected return. It is necessary to establish a data base for risk banking and a commitment to the full implementation of the principles of banking governance and to achieve full independence of the Internal Audit management in the Bank, in addition to the need to design a plan of internal audit in terms of the strategic objectives of the bank in the light of operational objectives and related activities and risk assessment on each of the strategic level and executive level (Abdel El-Fattah: 2008) in an attempt to determine a theoretical framework to audit in general and highlight the location of the internal audit of this framework and how they benefit from it and identify the scientific frame of the internal audit as a function within the entity to highlight the importance and usefulness of the internal audit process in general and administrative decisions process in particular, in light of the economic entity's need for the legitimate and effective application of the function of internal audit to assist it in performing its activities properly and to show the extent to which an internal audit contributes in activating taken decisions in their various managerial levels within the entity? It shows that the adoption of an internal audit of all its components would contribute significantly in the activation of the decisions taken at all levels, as the continued presence of the internal auditors in the institution qualifies them to be conversant with all the issues in it and increase as well the contribution of the audit of the internal decision-making process, and the conviction of the various managerial levels of internal audit as a function of effective within the entity will necessarily lead them to use this function to cope with various problems. (Obeirat and Nagaz: 2007).

where there is a need to identify the areas in which internal audit can provide value-added in the light of developments in accounting thought and recent trends of Internal Audit and its importance within the framework of a proposal to contribute in facing challenges and identify future directions for business organizations. It shows that there is an increase in value-added activities and actions that promote the right to contribute to the resources of the organization after fulfilling claims owed, such as: (Strategic Planning - Reengineering Business - Total Quality Systems - Environmental Audit) (Al-Ghobari Study: 2000).

As the role of the internal auditor has become a crucial one depending on the changing business environment and the nature of modern challenges, and this is what Basel Convention included, where it stipulated that it is incumbent on the internal audit to play a major role in the application and ensure the effectiveness of applying risk management procedures and methodology of risk assessment, as well as the assessment of the efficiency and effectiveness of the internal control system, because the internal audit plays this role in the mentioned framework is important, because it managed to reduce the risk, it is not a processor for only the current problem areas, but also expects problems and plays a crucial role in protecting the bank from risk, this requires extensive range of efforts between the internal auditor and regulatory institutions and parties concerned in this regard (Kamit 2008). The changes in trends and functions require awareness of internal auditors' role in risk management and demonstrate to them the value of the internal audit function in this regard, this is confirmed by SOX law (Sarbons Oxaly) (Sarens \& Beelde: 2006).

Showing the important role of the function of internal audit in the entities in providing a valuable service by evaluating the risk of audit and risk management of the entity requires 
internal auditor's understanding for three types of risks faced by the entity that is a risk of the external environment, the risks of business operations and information risk, there are also seven components of risk management of the entity that provides a conceptual framework for knowledge of the threats facing the entity include: (Environment, identify events, risk assessment, responding to the risk, control activities, information and communication, monitoring) and the internal audit function can play a great role and provide a valuable service through introducing risk management of that entity Kinney (2003).

\subsection{Risk Management Concept}

Governance guide defined risk management in banks as: "A regular process to identify and measure the risks faced by business and evaluate them according to the likelihood of occurrence and the damage that can be caused and to identify elements that the bank can incurred, avoided or secured against the occurrence (or any combination of the four) and determine the responsibility for processing and ensure the functioning of processes and raise the periodic reports immediately to the concerned authorities" (Monetary and Credit Council in Syria 2009).

Basel Committee has also pointed to the risks that are important factors affected on the financial and banking behavior and found in everything and form a cost on the profits of banks and other institutions, as it defined risk that it is such a situation where the possibility of deviation from a desirable result which is predicted or hope to achieve, while risk management considered as a process that protects and saves the assets and incomes of the individuals and projects, also viewed as administrative function of the business using a practical entrance to deal with risk, that is based on clear philosophy and follow a specific sequential steps (Juma': 2007 ).

Banking supervision authorities examine the practices and methods of risk management in banks, which requires knowledge and types of these risks, classification of these risks affected to the nature of activity of the entity, second Basel agreement document classified risks as follows:

1. Credit Risk: Arises from the possibility of inability or unwillingness of the borrower or the third party to fulfill his obligations in a timely manner to the bank, which led to cause economic losses for the bank, there are many factors lead to credit risk and occurrence of obstacles, either from an external factors related to economic conditions or factors related to the bank (such as the lack of good management for the customer query or not following up a loan), or a customer-specific factors (such as lack of good management for his project or the use of the loan in the allotted purpose).

2. Market Risk: Resulted from adverse changes or that are not in favor of the bank with respect to market prices, market risks are usually classified within the category of the risk of speculation as the price movements can result in profits or losses for the bank, market risk is divided into four types of risk: interest rates fluctuations risk, exchange rates exposures, financial securities fluctuations, fluctuations in commodity prices. 
3. Operational Risk: Risk resulted of loss arising from inadequate or failed internal processes, individuals and systems or as a result of external events. There is no doubt that the proper management of operational risk should stem from a sound policy that divides the bank's activities into business lines and losses are monitored for each activity or business line as a result of operational risk so that risk can be reduced to the greatest degree possible.

Then we will refer to the banking risks contained in the supporting documentation that are the liquidity risk, risk activities or electronic banking, strategic risk, compliance risks and legal and regulatory risks, (Hachad: 2005).

4. Liquidity Risk: It is the entity's inability to fulfill its obligations concerning providing the necessary funding or liquid assets.

5. Electronic Banking Activities Risk: Banks nowadays offer electronic banking activities so that they can occupy a good position in the competition between them, although the benefits provided for these activities, whether to the customer or the bank, but the security of these services is shrouded with a lot of risk.

6. Strategic Risk: It is a risk arising from making decisions or lack of decisions making for the management of the Bank's activities, which occur when the bank takes a wrong decision that leads to its loss or may lose the profits through the alternative opportunity, or the management didn't take a decision that could lead to profits for the bank or ward off the risks that the bank is exposed to.

7. Compliance Risks and Legal and Regulatory Risks: Compliance risk arises from the possibility of violating or not implementing the regulatory laws and rules, while the regulatory risk is caused by the possibility of changing the regulatory laws and rules in a way that lead to a negative impact on the bank's operations and its competitiveness.

\subsubsection{The Role of Internal Audit in Risk Management:}

The idea that risk must be embraced and eliminate it together by the entity contradict with the thought of the traditional internal audit, the internal audit practitioners sought in the past to eliminate the risk only, while definition of modern internal audit clarifies that we should care about risk management, as well as there are several professional standards issued by IIA that reflect the importance of the involvement of internal audit in the risk management system at the entity, where performance standard NO. / 2100 / states: Internal audit activity should help the entity to identify and assess important exposures for the risks and contribute to the improvement of risk management and control systems (Hammad: 2007).

The role of internal audit in risk management at the entity appeared in every stage of dealing with three risk factors, so controlling risks must be identified, evaluated, and then respond to them.

\section{Risk Identification}

Until the process of identifying risks done effectively, we should see each section of the entity, (disagreement points that are possible to reveal the focus point in operations), and the time at 
which we are considering what is going on within the entity in its different subdivision, we can see the entity from the outside to see the potential or imminent risk and so we can see all forms of risk, but not the risk that insures all or risks that we learn from the past, and in order for the risk's diagnosis to be effective, there are two imperatives (Al-Rawi: 2009):

1. Hazard identification should be a duty for a particular person: Managers at the entity are busy in financial management, production, marketing, sales, and may not rely on the diagnosis of one of the persons of risk unless it is explained as part of the functions assigned to it. On large entities this means the presence of risk manager, while in small-sized entities, this may mean to be within the job description of a manager in determining risk.

\section{The availability of risk identification tool for the person assigned to risk identification}

function: There are many ways to determine the risk and all of these methods have a role to play, which if collected together they can play a complex input compared to the methods used in the past, this point became a special course of action in large entities, so reliance on technical expertise and following the agreed upon standards, examination and surveillance system itself is no longer the way in determining the overall risk or highlight the risk point and therefore the chain of events that lead to disasters.

Where the process of identifying the risks surrounding the entity are the first stages of dealing with the risks, so in order to identify these risks, all members of the entity must be involved in determining the risks facing their activities, in which all managers at all levels in the entity can contribute in determining the surrounding risks through:

- Identify the risks faced by those responsible for implementation of activities.

- Identify the role of applied control systems to reduce the risks and the additional required control procedures.

- Identify those responsible for each type of risk and control procedures associated with it.

- Coordination in conducting a follow-up process of risk.

This can be achieved through cooperation between management and the internal auditors to develop assessment and improvement of controls to reduce exposure to risk, so the internal audit management is considered as a loop connection that through it, the workers in the entity can participate in the process of risk identification and evaluation of controls so as to make sure that the entity's goals have been achieved and this is known as self-control system (Prawitt: 2003).

The fact that the role of internal audit in determining the risk is to assist the entity's management, so it can do so through:

1. Conducting a scanning survey of surrounding risks to all entity's activities, so using this procedure leads to provide an early warning of the evolution of risk management, thus giving sufficient time to prepare strategies for the effective response to these risks (Treasury: 2004). 
2. Using traditional means of collecting information as making interviews with entity' managers and questionnaires forms.

3. Use some scientific methods such as self-assessment method and Control Risk Self-Assessment (CRSA) which defined in standard no. / 2120 / (IIA:2003) as: "A method includes a comprehensive self-assessment process through workshops to assess the risk and control and it is considered as effective method for administrators and internal auditors to cooperate in identifying risk assessment and control systems", the use of this method makes everyone in the entity contributes effectively in the process of identifying risks.

4. Internal auditor must not only focus on the risks that are directly related to the objectives of the activity, but must also focus on other risks associated with business environment in general, environmental risk or inherent risk as political, and natural risk (Cain: 2004).

The process of risk identification need skills, specific behaviors and different scientific and practical backgrounds for Internal Audit management team, as the internal auditor must recognize that the process of identifying the risks are interrelated and interdependent and therefore the identification that is an accurate and comprehensive process may be difficult in a specific degree and that the risks are varied and thus the selection process may not be characterized by stability in the components of each type, therefore the process of identifying risks must be characterized by flexibility or constantly reviewed by the Internal Audit management.

\section{Risk Assessment}

After determine risks, the assessment of these risks is followed, that means estimate the importance of the risks that have been identified to see which ones are important and less important and measure the impact of risk damage, which we believe to happen to the entity, this ensures dealing with all the major risks and direct resources to areas that are in urgent need and that have been identified through a standardized methodology (Hammad: 2007).

Risk assessment process that is surrounding the entity is considered the most important processes of dealing with risks through careful and proper assessment of them, with sound and correct evaluation of risks, sound methods will be proposed to deal with every kind of risks, taking an appropriate action in appropriate time by the management of the entity, where everyone in the entity plays a role in its risk management, since the management council is responsible for overseeing the management in the design and operation of the risk management system which has full responsibility for risk control, and has the primary responsibility of design and operate risk management system and the rest of the individuals in the entity have some responsibility for the successful implementation of this system, as internal audit assisted by its assessment of the effectiveness of the risk management system at the entity (Kinney: 2003).

Internal auditor must convey the process of risk assessment to the management in a way and manner that can be understood and through the method of analysis of the cost / benefit or comparisons operations in numbers, but some risk assessment can be subjected to evaluation in numbers especially the financial risks, while others can be evaluated digitally as the fame risks. 
Risk assessment process is based on two important factors (Treasury: 2004):

1. The accurate information that the internal auditor had gathered.

2. Time: Where the assessment process must be conducted in a timely manner as well as the output of the assessment process must be submitted to senior management in a timely manner to take appropriate decision at appropriate time and there are more risks can be controlled if the time is provided to assess and determine its outcome.

Thus internal auditor play an important role in assessment of the efficiency of risk management processes, standards guidance has made it clear for the U.S. internal auditors' complex, the following are the most important of what has been referred to within these standards (Al-Ramahi: 2004):

A) The role of the internal auditors in the process of assessment the efficiency of risk management is an advisory role in terms of helping the entity to identify, evaluate and apply appropriate methodologies for risk management through the examination and evaluation of risk management processes and make recommendations for improving the efficiency of these processes.

B) There are five key elements that must be achieved for risk assessments to achieve efficiency, which are:

- $\quad$ Identify and prioritize risks arising from the entity strategy and its activities.

- The board of directors and the senior management determine the level of acceptable risk for the entity.

- Design the methods of risk reduction and apply them to reduce the risk at an acceptable level of the board of directors and senior management.

- $\quad$ Periodic assessment of the risk through continuous monitoring of activities in order to judge the efficiency of control in risk management.

- $\quad$ Submitting periodic reports to the board of directors and senior management revealing the results of risk management processes and to inform shareholders about the risks and their strategic plan to control them.

C) The procedures followed by the internal auditor in gathering evidence to judge whether the above five objectives have been achieved, these are:

- $\quad$ Study and audit the developments and the current trends to obtain any information available to identify the risks that may affect the entity and its potential exposure and control procedures used in the risk management process and then evaluate them.

- Review the entity's policies and decisions of the Board of Directors and the audit committee notes about its reports submitted to identify the entity's strategy, philosophy and methodology of risk management and the level and acceptance of risk tolerance. 
- $\quad$ Audit previous reports of risk assessment prepared by the management and the internal and external auditors and any other regulatory authority that issued such reports.

- $\quad$ Conduct interviews with different administrative levels to determine the objectives of each business unit and related risks and how to manage and reduce risk and identify ongoing control activities.

- Assess the doers of operating activities to reduce risk and continuous supervision.

- $\quad$ Audit the impact of efficiency on the results of risk management and deliver reports in a timely manner.

- $\quad$ Audit administrative analysis completion about the risks and actions taken to control the subjects that have emerged as a result of risk management processes and to make suggestions for their development.

- Identify the effectiveness of self-assessment of risk made by management through direct testing and monitoring procedures and examine the accuracy of data used in the process of supervision and control.

- Audit any topics related to risk refers to the weakness in the application of risk processes and discuss them with the board of directors and the audit committee if the auditor finds it proper.

\subsection{Responding to Risk}

Dealing with risk proposal is to provide solutions on how to reduce the expected impact of these risks to achieve the entity's objectives, the Institute of Internal Auditors pointed out in the United Kingdom and Ireland that any taking action to deal with risk known in general as to respond to the risks (Cain:2004 ).

For good management of the risks, we need to classify types of response to the risk that guarantee us to stay in control of things and half of the ten responses to the risk as follows: (Hammad: 2007)

A-Remove (away): This is when the risk is big and is either not possible to fit at all, or the costs of this incapacitating are containment.

B-Controls Restricts: One of the best weapons to deal with risk is controls restricts, where it is always referred to good control systems that lead to reduced risks.

C- Emergency Circumstances: The useful response for risk with high impact and the probability of low occurrence based on taking arrangements for emergency response in the event of a risk, contingency plans will focus on the indicators that effect on the ongoing work of the entity, so that it is even with the preventive controls it will remain a chance of a risk.

D-Connect: It is the aspects of risk management, which often we can't understand, related to a connected part with high impact, (Either the probability of occurrence is medium or high), as control restricts may not address the risks associated with an acceptable level, in other words, it is a strategy to communicate these risks that affect the capacity of the entity to ensure success, 
that depends in delivering risk mainly on relations of trust between the giver and the recipient and the degree of consistency in the given messages.

E- Allowable: The risks (low / low), which resulted from our appreciation will not pose a threat to us, so that it can be tolerated, this position has been also associated with risks which decided to be high, where we have no choice but to accept what is before us .

F- About: When the risk is being assessed as having a high effect and but the probability of its occurrence is low, you may want to adopt a strategy based on the distribution of risk as much as possible and would be difficult to transfer probability of high occurrence risk, because all the parties concerned want to be re-compensated totally of the impact of the risk, the conversion shall not be more appropriateness when there is uncertainty.

G- Bear more: A dimension of risk management strategy is derived from the standpoint of the following risk, when showing appreciation (impact / probability of occurrence) that the present processes are low for both factors and that does not necessarily mean that everything is fine, risk management related to know where we should spend precious time, precious resources and areas (low / low) that are suitable for further investment (for commercial companies), or suitable for further innovative development (for public sector services).

H- Ask to Conduct Researches: Risk is about the uncertainty of the future, many of the risk management systems are very rigid in terms they are based on fast estimations and a record for risk which shows the business strategy that is agreed upon, the most advanced systems allow some time to think and one of the resolutions can include to request a research and survey for more information about the risk and its impact and the possibility of its actual occurrence.

I- Tell Someone: A method associated with a particular type of risks that require advice or consultation between specialists or top levels of supervisory to deal with the available information, where a team of people specialized in dealing with this information or communicate information are configured as to the Board of Directors, for example to take the resolution, this method is used in complex technical and technological matters (Owaid 2005).

J- Review Commitment: In response to risk, it is often ignored to focus on ways in which the controls are critical to mitigate the significant risks and ensure their desired image, controls that are facing more than one material risk is of particular importance, these controls can be reviewed and tested by internal auditors or by a dedicated team commissioned by the administration, that the response of risk management can rely on major officer supervisory, means: (as long as it works to mitigate risk) then the strategic is to focus on existing control and strengthened it as much as possible and ensure that they meet the required purpose.

Where decision making concerning dealing with risks is considered as the responsibility of senior management with entity, while the internal audit function can provide advice, alternatives and recommendations to senior management on how to deal with these risks and can propose appropriate methods to deal with each case risk situations, where this is Internal Audit Consulting Function (Bagshow:2002).

Dealing with risk should be based on the steps that have been taken in the previous stages, 
which are the process of identifying the risks and combining them in homogeneous groups, then risk assessment process, and propose methods of responding to risks.

\subsection{Field Study}

\section{Methodology of the Study and Its Population}

Study population is consisting of members of the board of directors and executives working in six public banks in Damascus, as well as from board members and executives working in six private banks in Damascus, where a questionnaire has been distributed on them using Five Likert Scale statement to view the sample of the study members' opinions on the terms contained in the questionnaire, five scales were assigned to find arithmetic means for the opinions of a sample; (5) assigned for (strongly agree) situation, and (4) for (agree), (3) for (neutral) and (2) for (disagree) and (1) for (strongly disagree). The questionnaire will be of two sections, the first section included demographic characteristics of respondents and the second section included phrases that measure respondents' views on the contribution of internal audit in risk management.

When conducting statistical analysis, arithmetic means and percentages have been adopted for respondents, in accordance to three groups in order for further clarification, as follows:

1. Approvers Rates: Include percentage of strongly consenting and relative approvers together.

2. Neutrals Rates: Include percentage of those who answered as neutral for each paragraph of the questionnaire.

3. Non-Approvers Rates: Include the proportion of strongly disagree and the proportion of disagree together.

The degree of contribution has been identified in accordance with the arithmetic means for individuals 'answers, they classified them into three levels that represent the degree of contribution, as follows:

1. High Degree Contribution: It is the contribution that came in paragraphs that the arithmetic means were equal to or greater than (3.5) and which approached a bit to the nearest integer number to become (4) and it is in the same scale that assigned to agree case and thus includes the degree of agree and strongly agree.

2. Medium Degree Contribution: It is a contribution for paragraphs that the arithmetic means were confined quarters of them between equal to or less than (3.5) and equal to or greater than (2.5) which, if rounded to the nearest integer number, it will become (3) and it is the same scale that assigned for neutral case.

3. Low Degree Contribution: It is a contribution for paragraphs that arithmetic means were less than (2.5), and if it rounded to the nearest integer number, it will become (2) which are the same scale that assigned for disagree case, and thus includes the degree of disagree and strongly disagree. 


\section{Macrothink}

The number of returned questionnaires and suitable for the analysis were 60 questionnaires from public banks and 48 questionnaires from private banks.

\section{Tests for Study Tool}

\section{- Virtual Honesty}

To ensure that the scale that was used in the study measures what it is supposed to measure (Zikond: 1994), virtual honesty and sincerity test has been conducted in order to be sure that the statements contained in the study tool lead to collect accurate data (Al-Omari: 2001). The questionnaire has presented on a group of faculty members in Economics - Department of Accounting and a number of experts working in the banks, so as to give their comments and their point of views in the questionnaire in terms of suitability to measure the contribution of the internal audit function in risk management where they were taking their observations as conducted a previous test for the questionnaire based on arbitrators' observations and pre-test results and it has modified the questionnaire.

\section{- Tool Stability}

Internal coherence coefficient Cronbach's alpha has been used ${ }^{(1)}$ the answers and the value of Cronbach's alpha for all phrases were (0.955) that means that there is an internal coherence in identifying any study that can rely on collected data through them.

\section{Used Statistical Methods}

For the purposes of achieving the objectives of the study, the following statistical methods had been used:

1. Descriptive Statistical Methods: These methods have been used to get general indicators of the characteristics of the study population and characterization of the study variables and measure the contribution of the internal audit function in risk management that included frequency distribution and percentage rates and metrics of central tendency (mean) and scatter measures (standard deviation).

2. T-Test: In order to test whether the value of arithmetic means of respondents' answers are different from a specific value to test hypotheses.

Statistical Package for Social Sciences (SPSS) has been used for the analysis of the study data.

Second: Data Analysis and Display the Results

Data entry has been inserted for Statistical Package for Social Sciences (SPSS) program, which is used for the analysis of the study data.

\subsection{Characteristics of the Respondents}

For the purposes of identifying the demographic characteristics of the respondents, scientific specialization variables were selected: Qualification, Workplace, Job Title, Years of Experiences, duplicates and percentages were extracted and analyzed as shown in table (1) 
Table 1. The Characteristics of the Respondents

\begin{tabular}{|c|c|c|c|}
\hline \multicolumn{2}{|l|}{ Variable } & \multirow{2}{*}{$\begin{array}{c}\text { Repetition } \\
40\end{array}$} & \multirow{2}{*}{$\begin{array}{c}\text { Percentage } \\
34.2 \\
\end{array}$} \\
\hline Specialization & Accounting & & \\
\hline & $\begin{array}{l}\text { Banking and Financial } \\
\text { Sciences }\end{array}$ & 19 & 16.2 \\
\hline & Business Administration & 25 & 21.4 \\
\hline & Economy & 18 & 15.4 \\
\hline & Other & 15 & 12.8 \\
\hline \multirow[t]{5}{*}{ Qualification } & High School & 1 & 0.9 \\
\hline & Diploma & 8 & 6.8 \\
\hline & Bachelor & 68 & 58.1 \\
\hline & Master & 23 & 19.7 \\
\hline & Doctorate & 17 & 14.5 \\
\hline \multirow[t]{2}{*}{ Workplace } & Private Bank & 47 & 40.2 \\
\hline & Public Bank & 70 & 59.8 \\
\hline \multirow[t]{2}{*}{ Job Title } & $\begin{array}{l}\text { Member of the Board of } \\
\text { Directors }\end{array}$ & 42 & 35.9 \\
\hline & Executive Director & 75 & 64.1 \\
\hline \multirow[t]{5}{*}{ Years of Experience } & Less than 5 Years & 22 & 18.8 \\
\hline & From 5 To less than 10 & 46 & 39.3 \\
\hline & From 10 To less than 15 & 33 & 28.2 \\
\hline & $15+$ Years & 16 & 13.7 \\
\hline & & 117 & 100.0 \\
\hline
\end{tabular}

Table (1) shows that $(92.3 \%)$ of the respondents hold bachelor, master and doctorate degrees and the highest percentage of scientific specialization, (34.2\%) of accounting as (18.8\%) their experience are less than five years, while the remaining of $(80.2 \%)$ their experiences more than five years.

Based on the above, it shows that the respondents covered in the study have a scientific qualifications, specialization and expertise to answer a questionnaire paragraphs study and have the knowledge in the subject of the study, which means there is reliability in their responses and we can rely on them in a high credibility.

\section{Public Banks}

(20) paragraphs have been identified that indicate in their entirety and measure the contribution of internal audit in risk management in Syrian public banks, arithmetic means have been extracted from the largest to the smallest, standard deviations, the degree of contribution, the percentage of those who answered "agree" "significantly agree" or "very significantly agree", and those who answered "moderately agree" and disagree in its two degrees "disagree" and "significantly disagree" in each paragraph of these paragraphs, which prescribed in table (2) sorted by arithmetic means. 
The table refers that the arithmetic means of the answers to the paragraphs of this area ranging for the paragraphs related to: Internal audit assured the existence of appropriate controls to address the risks in the bank, audit procedure works to identify potential threats that may threatened bank's goals, so the internal audit helps to test and implement in response to risk by undertake it and find treatment to it, which indicates that the internal audit do what came in paragraphs to a large extent, as the arithmetic means for them if they are rounded to the nearest whole number they become (4) which is the value of approval on the scale used in this study.

It is noted from the table that the arithmetic mean was reached (4.01) for each of the paragraphs concerning internal audit confirmed of the existence of appropriate controls to address the risks in the bank, internal audit work to assess the efficiency and effectiveness of controls to address the risks in the bank.

Table 2. Views and Perceptions of Respondents about the Extent of the Contribution of Internal Audit in Risk Management in Syrian Public Banks

\begin{tabular}{|c|c|c|c|c|c|c|}
\hline Paragraph & Agree & Neutral & disagree & $\begin{array}{l}\text { Arithmetic } \\
\text { Mean }\end{array}$ & Standard & $\begin{array}{l}\text { Contribution } \\
\text { Degree }\end{array}$ \\
\hline $\begin{array}{l}\text { Internal Audit confirmed of the existence of } \\
\text { appropriate controls to face the risks in the bank. }\end{array}$ & 82.9 & 15.7 & 1.4 & 4.01 & 0.65 & Great \\
\hline $\begin{array}{l}\text { Internal audit work to assess the efficiency and } \\
\text { effectiveness of controls to face the risks in the } \\
\text { bank. }\end{array}$ & 87.1 & 11.4 & 1.4 & 4.01 & 0.58 & Great \\
\hline $\begin{array}{l}\text { Internal audit deliver reports to the bank's senior } \\
\text { management about the results of the evaluation } \\
\text { of the efficiency and effectiveness of controls to } \\
\text { face the risks. }\end{array}$ & 84.3 & 12.9 & 2.9 & 3.99 & 0.65 & Great \\
\hline $\begin{array}{l}\text { Internal audit confirmed of taking the necessary } \\
\text { actions for risk management in the bank. }\end{array}$ & 80.0 & 18.6 & 1.4 & 3.96 & 0.65 & Great \\
\hline $\begin{array}{l}\text { Internal audit works as an advisor when } \\
\text { preparing for risk mitigation strategies in the } \\
\text { bank. }\end{array}$ & 84.3 & 14.3 & 1.4 & 3.94 & 0.56 & Great \\
\hline $\begin{array}{l}\text { Internal audit contributed in submit proposals to } \\
\text { eliminate risks in the bank. }\end{array}$ & 87.1 & 11.4 & 1.4 & 3.94 & 0.59 & Great \\
\hline $\begin{array}{l}\text { Internal audit confirms the existence a developed } \\
\text { emergency plan which is reviewed periodically } \\
\text { and regularly. }\end{array}$ & 65.7 & 27.1 & 7.1 & 3.84 & 0.90 & Great \\
\hline $\begin{array}{l}\text { Internal audit helps to deliver information about } \\
\text { risks in an order manner and to the appropriate } \\
\text { levels in the bank. }\end{array}$ & 74.3 & 18.6 & 7.1 & 3.81 & 0.77 & Great \\
\hline $\begin{array}{l}\text { Internal audit works with other parties in the } \\
\text { bank to determine the levels of risk accepted by } \\
\text { the Board of Directors. }\end{array}$ & 70.0 & 20.0 & 10.0 & 3.71 & 0.80 & Great \\
\hline
\end{tabular}




\begin{tabular}{|c|c|c|c|c|c|c|}
\hline $\begin{array}{l}\text { Internal audit helps in creating policies and } \\
\text { processes for risk management in case of crises } \\
\text { that are likely to occur. }\end{array}$ & 67.1 & 30.0 & 2.9 & 3.71 & 0.64 & Great \\
\hline $\begin{array}{l}\text { Internal audit works with other parties in the } \\
\text { bank to assess risk and arrange them according } \\
\text { to their priorities. }\end{array}$ & 67.1 & 24.3 & 8.6 & 3.69 & 0.77 & Great \\
\hline $\begin{array}{l}\text { Internal audit confirms existence of general } \\
\text { framework for risk management to help in } \\
\text { developing a range for risks management and } \\
\text { procedural operations necessary for them in the } \\
\text { bank. }\end{array}$ & 65.7 & 25.7 & 8.6 & 3.66 & 0.81 & Great \\
\hline $\begin{array}{l}\text { Internal audit works with the responsible party } \\
\text { for risk management to conduct self-assessment } \\
\text { of risk. }\end{array}$ & 64.3 & 27.1 & 8.6 & 3.66 & 0.78 & Great \\
\hline $\begin{array}{l}\text { Internal audit works in testing the developing } \\
\text { and improving risks management of the bank. }\end{array}$ & 61.4 & 30.0 & 8.6 & 3.64 & 0.80 & Great \\
\hline $\begin{array}{l}\text { Internal audit performs auditing of major risks in } \\
\text { the bank management and submit related } \\
\text { reports. }\end{array}$ & 61.4 & 30.0 & 8.6 & 3.64 & 0.80 & Great \\
\hline $\begin{array}{l}\text { Internal audit works to develop procedures and } \\
\text { methods aimed at reducing the risks or minimize } \\
\text { the effects of negative results. }\end{array}$ & 62.9 & 30.0 & 7.1 & 3.64 & 0.74 & Great \\
\hline $\begin{array}{l}\text { Internal audit reviews any related risk topics that } \\
\text { refer to the weakness in the application of risk } \\
\text { management processes. }\end{array}$ & 58.6 & 35.7 & 5.7 & 3.60 & 10.71 & Great \\
\hline $\begin{array}{l}\text { Internal audit works through its control to avoid } \\
\text { risks in the bank. }\end{array}$ & 60.0 & 21.4 & 18.6 & 3.51 & 0.96 & Great \\
\hline $\begin{array}{l}\text { Internal audit works to identify potential threats } \\
\text { that might threaten a bank's goals. }\end{array}$ & 55.7 & 28.6 & 15.7 & 3.49 & 0.86 & Average \\
\hline $\begin{array}{l}\text { Internal audit helps in testing and implementing } \\
\text { risks response by finding treatment. }\end{array}$ & 50.0 & 41.4 & 8.6 & 3.49 & 0.76 & Average \\
\hline All Paragraphs & 20.5 & 26.5 & 53.0 & 3.75 & 0.41 & Great \\
\hline
\end{tabular}

The value of arithmetic means in the second group has ranged between (3.94-3.99), and this group includes paragraphs related to that internal audit raises reports for senior management at the bank on the results of the evaluation of the efficiency and effectiveness of controls to confront the risks, internal audit assures taking the appropriate measures of risk management at the bank, the internal audit works also to provide advice in the preparation of risk mitigation strategies in the bank, also internal audit contributes in submitting proposals to mitigate risks in bank, internal audit assures the existing of emergency plan which reviewed periodically and systematically, and in helping internal audit to deliver information about the risks in appropriate levels in the bank. 
In the same context, the arithmetic mean of the two paragraphs relating to the internal audit that works with others in the bank and determine the accepted levels of risk by the board of directors, internal audit helps to create policies and processes for risk management in case of crises are likely to occur, with (3.81) (3.84), respectively.

While the arithmetic mean value ranged between (3.60-3.69) for paragraphs relating to the internal audit works with other parties in the bank to assess risks according to their priorities, internal audit assures the existence of a general framework for risk management that helps to develop a range of risks management and procedural processes necessary for risk management in the bank, internal audit works with the responsible party of risk management to conduct self-assessment of risk, also internal audit works to test development and improvement of risk management processes in the bank, it also reviews the main risks management of the bank and deliver reports, internal audit aimed at reducing the risks or minimizing the negative effects resulting from them, internal audit reviews risks related to the weakness in the application of risk management processes.

We noted that the value of arithmetic mean of all the paragraphs relating to the contribution of internal audit in risks management amounted to (3.75) which is the approved value in the scale used in the study, which means that internal audit in the public banks of Syrian contributes to support risk management.

While according to the consenting rates, they have ranged between (50-87.1\%), while the value of agreed in medium-degree ranged between (11.4-41.4\%) that means that the majority of the respondents in Syrian public banks see that internal audit contributes in risk management in the bank.

A non-consenting ratios on the paragraphs of this area amounted to (4.1 to $6.18 \%)$ which are very low ratios since the percentages of paragraphs were: internal audit works through its regulatory activity to avoid risks in the bank, internal audit works to identify potential threats that may threatened the objectives of the bank, internal audit works with other parties in the bank to determine acceptable levels of risk from the board of directors (8.6\%) $(15.7 \%)$ and $(10 \%)$, they decreased to reach $(8.6 \%)$ for paragraphs: Internal audit works with other parties in the bank to assess risks and arrange them according to priorities, internal audit assures the existence of a general framework for risk management that helps to develop a range of risk management and procedural processes required to manage the risks in the bank, internal audit works with the agency responsible for risk management to conduct self-assessment of risk, internal audit works to test development and improvement of risk management processes in the bank, internal audit reviews the main risk management in the bank and deliver reports, internal audit helps on testing the implementation by responding to risks by bearing them and find treatment for them.

While the percentage was (7.1\%) for the paragraphs: Internal audit assures the existence of a developed emergency plan that are reviewed periodically and regularly, internal audit helps in delivering information about the risks in an appropriate manner and levels in the bank, internal audit works to develop procedures and methods aimed at reducing the risk or reduce the resulting negative effects. 
It is worth mentioning that the ratio of non-consenting reached (1.4\%), the paragraphs: Internal audit assures the existence of appropriate controls to face the risks in the bank, internal audit works in evaluation the efficiency and effectiveness of controls to face the risks in the bank, internal audit assures taking necessary procedures of risks management in the bank, internal audit works to offer the advice when preparing risk illumination bank strategies, internal audit contributes in providing proposals to illuminate risks in bank.

From the above, we note that there is considerable agreement that the Syrian public banks are doing all what is stated in the paragraphs of this area and therefore the internal audit in a bank contributes to risk management.

\section{Private Banks}

(20) paragraphs have been identified that indicate in their entirety and measure the extent of senior management in the Syrian private banks to the importance of the contribution of internal audit in risk management, the arithmetic means have been extracted from the largest to the smallest, standard deviations, the degree of contribution and the percentage of those who agree in its two forms "significantly agree" or "in a high degree agree" and who responded to agree moderately and disagree in its two forms or significantly disagree for each paragraph of these paragraphs and prescribed by the following table arranged by arithmetical means.

Table 3. Opinions and Perception of Respondents about the Extent of the Contribution of Internal Audit in Risk Management in Syrian Private Banks

\begin{tabular}{|c|c|c|c|c|c|c|}
\hline Paragraph & Agree & Neutral & 1 Disagree & $\begin{array}{l}\text { Arithmetic } \\
\text { Mean }\end{array}$ & Standard & $\mid \begin{array}{l}\text { Degree of } \\
\text { Contribution }\end{array}$ \\
\hline $\begin{array}{l}\text { Internal audit makes sure of the existence of a } \\
\text { contingency plan that is reviewed periodically } \\
\text { and regularly. }\end{array}$ & 85.1 & 10.6 & 4.3 & 4.21 & 0.81 & Great \\
\hline $\begin{array}{l}\text { Internal audit makes sure of the existence of } \\
\text { appropriate controls to face the risks in the bank. }\end{array}$ & 93.6 & 4.3 & 2.1 & 4.19 & 0.71 & Great \\
\hline $\begin{array}{l}\text { Internal audit makes sure of implementing } \\
\text { necessary actions for risk management in the } \\
\text { bank. }\end{array}$ & 78.7 & 17.0 & 4.3 & 4.17 & 0.87 & Great \\
\hline $\begin{array}{l}\text { Internal audit contributes in submitting } \\
\text { proposals in order to reduce the risks in the } \\
\text { bank. }\end{array}$ & 93.6 & 4.3 & 2.1 & 4.17 & 0.60 & Great \\
\hline $\begin{array}{l}\text { Internal audit makes sure of implementing } \\
\text { general framework for risks management which } \\
\text { helps to develop a range of necessary } \\
\text { procedures operations of risks management in } \\
\text { the bank. }\end{array}$ & 76.6 & 19.1 & 4.3 & 4.15 & 0.88 & Great \\
\hline $\begin{array}{l}\text { Internal audit works to provide advice when } \\
\text { preparing risk elimination strategies in the bank. }\end{array}$ & 85.1 & 14.9 & 0.0 & 4.11 & 0.63 & Great \\
\hline Internal audit works with the responsible party & 83.0 & 17.0 & 0.0 & 4.02 & 0.61 & Great \\
\hline
\end{tabular}




\section{Macrothink}

Journal of Management Research

ISSN 1941-899X

2016, Vol. 8, No. 3

\begin{tabular}{|c|c|c|c|c|c|c|}
\hline $\begin{array}{l}\text { of risks management to conduct self-assessment } \\
\text { of risks. }\end{array}$ & & & & & & \\
\hline $\begin{array}{l}\text { Internal audit works to evaluate the efficiency } \\
\text { and effectiveness of controls to face the risks in } \\
\text { the bank. }\end{array}$ & 85.1 & 8.5 & 6.4 & 4.00 & 0.83 & Great \\
\hline $\begin{array}{l}\text { Internal audit works in testing, developing and } \\
\text { improving risk management processes in the } \\
\text { bank. }\end{array}$ & 70.2 & 23.4 & 6.4 & 4.00 & 0.93 & Great \\
\hline $\begin{array}{l}\text { Internal audit works through its internal control } \\
\text { to avoid risks in the bank. }\end{array}$ & 74.5 & 21.3 & 4.3 & 3.98 & 0.82 & Great \\
\hline $\begin{array}{l}\text { Internal audit reviews the main risks } \\
\text { management in the bank and submit necessary } \\
\text { reports. }\end{array}$ & 72.3 & 12.8 & 14.9 & 3.87 & 1.08 & Great \\
\hline $\begin{array}{l}\text { Internal audit helps in delivering information } \\
\text { about the risks orderly and in appropriate levels } \\
\text { in the bank. }\end{array}$ & 68.1 & 8.5 & 23.4 & 3.74 & 1.13 & Great \\
\hline $\begin{array}{l}\text { Internal audit helps in testing and implementing } \\
\text { responding to the risks by finding treatment for } \\
\text { them. }\end{array}$ & 66.0 & 27.7 & 6.4 & 3.74 & 0.79 & Great \\
\hline $\begin{array}{l}\text { Internal audit reviews any related risks topics } \\
\text { refer to the weakness in the application of risk } \\
\text { management processes. }\end{array}$ & 63.8 & 23.4 & 12.8 & 3.72 & 0.95 & Great \\
\hline $\begin{array}{l}\text { Internal audit raises reports for the bank's senior } \\
\text { management on the results of the evaluation of } \\
\text { the efficiency and effectiveness controls to face } \\
\text { the risks. }\end{array}$ & 61.7 & 21.3 & 17.0 & 3. 1070 & 1. & Great \\
\hline $\begin{array}{l}\text { Internal audit works with other parties in the } \\
\text { bank to determine the levels of risk accepted by } \\
\text { the board of directors. }\end{array}$ & 63.8 & 23.4 & 12.8 & 3.68 & 0.91 & Great \\
\hline $\begin{array}{l}\text { Internal audit helps to create policies and } \\
\text { processes for risk management in crises that are } \\
\text { likely to occur. }\end{array}$ & 61.7 & 25.5 & 12.8 & 3.64 & 0.90 & Great \\
\hline $\begin{array}{l}\text { Internal audit works with other parties in the } \\
\text { bank to assess risks and arrange them according } \\
\text { to their priorities. }\end{array}$ & 55.3 & 29.8 & 14.9 & 3.60 & 0.97 & Great \\
\hline $\begin{array}{l}\text { Internal audit works to identify potential threats } \\
\text { that might threaten the bank's goals. }\end{array}$ & 55.3 & 21.3 & 23.4 & 3.47 & 1.14 & Average \\
\hline $\begin{array}{l}\text { Internal audit works on developing methods } \\
\text { aimed at reducing the risks or minimizing the } \\
\text { resulting negative effects. }\end{array}$ & 55.3 & 10.6 & 34.0 & 3.38 & 1.13 & Average \\
\hline All paragraphs & 24.3 & 26.6 & 49.2 & 3.88 & 0.55 & Great \\
\hline
\end{tabular}




\section{Ml Macrothink}

The foregoing percentages confirm that there is agreement among respondents that the internal audit conducts the requirements and works and contributes in the risk management in Syrian private banks.

\section{C- The Differences between the Two Sectors}

The differences between the arithmetic means for the responders' answers from private and public banks were extracted, the following table shows the value of (t) and paragraphs are arranged according to the amount of the differences between the means.

Table 4. Differences between the Views and Perceptions of Respondents about the Extent of the Contribution of Internal Audit in Risk Management in Syrian Private and Public Banks

\begin{tabular}{|l|c|c|c|c|c|c|c|}
\hline Paragraph & \multicolumn{2}{|c|}{ Private banks } & \multicolumn{2}{c|}{ Public banks } & \multicolumn{2}{c|}{ Test (t) Differences } \\
\hline Paragraph & $\begin{array}{c}\text { The Arithmetic } \\
\text { Mean }\end{array}$ & $\begin{array}{r}\text { Standard } \\
\text { Deviation }\end{array}$ & $\begin{array}{c}\text { The } \\
\text { Arithmetic } \\
\text { Mean }\end{array}$ & $\begin{array}{c}\text { Standard } \\
\text { Deviation }\end{array}$ & Differences & T & sig \\
\hline $\begin{array}{l}\text { The contribution of internal } \\
\text { audit in risks management }\end{array}$ & 3.88 & 0.55 & 3.75 & 0.41 & 0.13 & 1.47 & 0.143 \\
\hline
\end{tabular}

These differences are statistically significant at the level of (0.05), but the difference between the overall average for all paragraphs of this field (0.13), where the value of the calculated $(\mathrm{t})$ test for the sample mean is (1.47), where the level of moral calculated ( $\mathrm{t}$ ) value was (1.43) which is more than (0.05) as indicated in the last column of the table, which means that there are no statistically significant differences in the degree of internal contribution in risk management in public and private bank sectors, but all of these banks are managing risk to the same degree, this may be due to the importance of internal audit, regardless of the nature of the bank where it worked at the same level of risk in the market.

\section{Testing Hypotheses}

\section{First Hypothesis}

H0: Internal audit does not contribute in risks management in Syrian public banks.

Using (T) test to test this hypothesis and to learn if the arithmetic mean value of the total level of the field, which measures more than the value of the test of (3.5), which represents the degree of approval on the Five Likert Scale used in this study, and where if it approached to the nearest decimalit will become (4), and it expresses the mean, which is taken to express the value of the statistical $(t)$ test per sample, so accept the hypothesis if it indicates $(t)$ significant level of significance and reject the hypothesis, if (a) equal significant level (0.05) less than ( $t)$ (0.05). until this study is adopted. 
First Hypothesis Test Results in Public Banks

\begin{tabular}{|l|l|l|l|l|l|}
\hline \multicolumn{1}{|c|}{ First Hypothesis } & $\begin{array}{c}\text { Arithmetic } \\
\text { Mean }\end{array}$ & $\begin{array}{l}\text { Standard } \\
\text { Deviation }\end{array}$ & $\begin{array}{l}\text { Application } \\
\text { Degree }\end{array}$ & Value $t$ & Sig \\
\hline $\begin{array}{l}\text { Internal audit contributes in risks management in public } \\
\text { banks }\end{array}$ & 3.75 & 0.41 & Agree & 5.11 & 0.000 \\
\hline
\end{tabular}

The table indicates that the value of $(\mathrm{T})$ is (5.11) and in terms of the statistical minimum less than (0.0005), which is less than the level of significance $(a=0.05)$ used in this research, and that the value of calculated $(\mathrm{T})$ is greater than the value of $(\mathrm{T})$ at the level of significance ( $0.05)$, that is the value of arithmetic mean of the answers to this area is larger than the value of the stake at the level of statistical significance $(a=0.05)$.

Based on the rule that said of the acceptance of null hypothesis and refused the alternative one, if the calculated $(\mathrm{T})$ value was less than the index $(\mathrm{T})$ value and refused the null hypothesis and accept the alternative one if the calculated $(\mathrm{T})$ value is larger than the index $(\mathrm{T})$, accordingly, we will reject the null hypothesis and accept the alternative one which say: Internal audit contributes in risks management in public bank sector.

\section{Second Hypothesis}

H0: Internal audit does not contribute in risk management in Syrian private banks.

Using $(t)$ test to test this hypothesis and to find out whether the arithmetic mean value of the macro-level of the field, which measures the second hypothesis increases the value of the stake which amounted to (3.5), which represents the degree of approval on the Five Likert Scale used in this study, where if it approached to a nearest decimal status, it will become (4), it reflects the average, which is to be made to express the value of the statistical ( $t$ ) test per sample, so we accepted the hypothesis whether $(t)$ is greater than or equal to the level of significance adopted until this study $(a=0.05)$ and rejecting the hypothesis whether $(t)$ is less than $(a=0.05)$.

Table 5. Second Hypothesis Test Results in Private Banks

\begin{tabular}{|l|c|c|c|c|c|}
\hline \multicolumn{1}{|c|}{ Second Hypothesis } & $\begin{array}{c}\text { Arithmetic } \\
\text { Mean }\end{array}$ & $\begin{array}{c}\text { Standard } \\
\text { Deviation }\end{array}$ & $\begin{array}{c}\text { Degree of } \\
\text { Contribution }\end{array}$ & $\begin{array}{c}(\mathrm{t}) \\
\text { Value }\end{array}$ & $\mathrm{Sig}$ \\
\hline $\begin{array}{l}\text { Internal Audit contributes in risks management in private } \\
\text { banks }\end{array}$ & 3.88 & 0.55 & Great & 4.75 & 0.000 \\
\hline
\end{tabular}

(t) value is (4.75) and with a statistical term, as it is less than the level of significance $(a=0.05)$ used in this research, and that the value of calculated $(t)$ is greater than the index $(t)$ value at the level of significance $(a=0.05)$ ), as the arithmetic mean of the answers to this area is larger than the value of the stake at the level of statistical significance $(a=0.05)$.

Based on the rule that accept the null hypothesis and reject the alternative one if the calculated $(t)$ value is less than the index ( $t$ ) value and reject the null hypothesis and accept the alternative one if the value of the calculated $(\mathrm{t})$ is greater than the index $(\mathrm{t})$ value, accordingly, we reject the null hypothesis and accept the alternative one which says: Internal audit contributes in risks management in public banks. 


\section{Third Hypothesis}

H0: There are no statistically significant differences between the contribution of internal audit in risks management between private and public banks sector.

Table 6. The Results of the Third Test Hypothesis (The Differences of the Sector Type Impact)

\begin{tabular}{|c|c|c|c|c|c|c|c|}
\hline \multirow[t]{2}{*}{ Area } & \multicolumn{2}{|c|}{ Sector $1 \mathrm{n}=47$} & \multicolumn{2}{|c|}{ Sector $2 \mathrm{n}=70$} & \multirow{2}{*}{ Differences } & \multirow{2}{*}{ Value } & \multirow[t]{2}{*}{ Sig } \\
\hline & $\begin{array}{c}\text { Arithmetic } \\
\text { Mean }\end{array}$ & $\begin{array}{c}\text { Standard } \\
\text { Deviation }\end{array}$ & $\begin{array}{c}\text { Arithmetic } \\
\text { Mean }\end{array}$ & $\begin{array}{l}\text { Standard } \\
\text { Deviation }\end{array}$ & & & \\
\hline $\begin{array}{l}\text { Internal audit contributes in risk } \\
\text { management in the Syrian public and } \\
\text { private banks }\end{array}$ & 3.88 & 0.55 & 3.75 & 0.41 & 0.13 & 1.47 & 0.143 \\
\hline
\end{tabular}

The value of $(t)$ is (1.47) and its significance level is $(0.143)$ that the value of the arithmetic means the respondents' answers from the private and public sector were around this field indicates that the value of $(\mathrm{t})$ increased more than (0.05) used in this research, which means that the value of the arithmetic mean of the respondents' answers from the private sector does not differ from the arithmetic mean value of respondents' answers from the public sector, this means that there are no statistically significant differences between the contribution of internal audit in risks management between private and public banks sector.

And thus we accept the null hypothesis, which says: There are no statistically significant differences between the contributions of internal audit in risks management between private and public banks sector.

\section{Findings and Recommendations}

A: Research Results: The research found the following results:

1. Internal audit contributes in risk management in Syrian public banks.

2. Internal audit contributes in risk management in Syrian private banks.

3. There are no statistically significant differences between the contribution of internal audit in risk management between private and public banks sector.

B: Recommendations: Based on the findings of this research results, the following recommendations appeared:

1. The need to conduct training courses for workers in the internal audit function, in order to keep abreast of ongoing professional developments in any field which is related to the internal audit function.

2. The need for further work to clarify the importance of the banks' internal audit management and through the issuance of instructions and necessary legislations and the establishment of seminars and business studies. 


\section{Macrothink}

Journal of Management Research

ISSN 1941-899X

2016, Vol. 8, No. 3

3. An internal audit committee should be formed within Legal Accountants Society in Syria; its mission is to develop the internal auditor and issue special criteria that agree with the Syrian economic laws.

4. The necessity of professional organizations' cooperation for accounting, auditing and regulatory bodies in Syria with the rest of the professional organizations in the Arab countries to establish an Arabic complex for internal auditor to rehabilitate them and give them a professional certification to carry out their roles under the new framework for the exercise of the profession.

\section{References}

Abdel Fattah, Mohamed Abdel Fattah Mohamed. (2008). A proposed framework for the development of the role of internal audit in the activation of banking risk management, accounting thought, specialized scientific journal published by the Department of Accounting and Auditing, Faculty of Commerce, Ain Shams University twelfth year, September 2008, Issue 2.

Al-Ghoubari, \& Ayman Fathi Ahmed. (2000). Recent trends of internal audit and its importance in determining future trends. Journal of Accounting, Management and Insurance, Faculty of Commerce, 56, 305-331. Cairo University.

Al-Kabbani, Thana' Ali. (2006). Internal Audit under e-operating, Al-Jame'ia publishing house, Alexandria, p 19.

Al-Qadi, Hussein Youssef, Dahdouh, Hussein Ahmed, Garit, \& Essam Ne'ma. (2008). Internal Audit, Damascus University.

Al-Ramahi, \& Zahir Atta. (2004). The development of an audit risk-based method in Jordanian banks, study for a doctorate degree in accounting, Amman Arab University, p .175 - 176.

Al-Rawi, Khalid Wahib. (2009). Financial Risk Management, Dar Al-Maseera for publication, distribution and printing, Amman, Jordan, p. 14-16.

Al-Sahen, Abdel Fattah, Saraya, Mohamed El-Sayed, Shehata, \& Shehata Al-Sayed. (2006). Control and Modern internal audit, Faculty of Commerce, University of Alexandria.

Al-Sawah, Nader Shaaban Ibrahim. (2005). The impact of electronic transactions and automated processes on the methodology and methods of internal audit in commercial banks, Master Thesis, Library of the Faculty of Commerce, University of Menoufia.

Al-Wardat, Khalaf Abdullah. (2006). Internal Audit between theory and practice in accordance with the standards of internal audit, Amman, Al-Warraq Foundation.

Bagshow, K. (2002). The Role of Internal Auditing in Risk Management. Student Accountant, March, p.33.

Cain, J. (2004). In the Spotlight, Internal Auditing \& Business Risk, IIA UK \& Ireland, May, p.3,4. 
Owe Zaki Mohammed Mubarak. (2005). The role of internal audit in improving the economic performance in units, Master of Accounting, Faculty of Commerce, Ain Shams University, Egypt, p. 104-105.

Gerrit Sarens, \& Ignace De Beelde. (2006). Internal Auditors' Perception about Their Role in Risk Management: A Comparison Between US and Belgian Companies. Managerial Auditing Journal, 21(1), 63-80. https://doi.org/10.1108/02686900610634766

Ghali, George Daniel. (2003). Development of the audit profession to address contemporary problems and challenges of the third millennium, Al-Jame'ia publishing house, Alexandria, 2003.

Goodwin, J., \& Kent, Pamela. (2006). The Use of Internal Audit by Australian Companies. Managerial Auditing Journal, $\quad$ Bradford, $\quad 21(1 / 2), \quad 81$. https://doi.org/10.1108/02686900610634775

Hammad, Tarek Abdel Aal. (2007). Corporate Governance (Companies, public and private banks sector - concepts - principles - testing - Requirements), Faculty of Commerce, Ain Shams University, Al-Jame'ia publishing house, Egypt, 349-355

Hashad, Nabil. (2005). Your guide to bank's risk management, Basel Encyclopedia, Part II, Beirut, Lebanon, 35-45.

Institute of Internal Auditors, The Standards of Internal Auditing, IIA. (2007). www.theiia.org.

International Federation of Accountants. (2009). Handbook of International Auditing and assured ethics, translation of Legal Arab of Accountants Society, Amman, Jordan.

Juma, Ahmed Helmi, \& Al-Barghouti, Samir. (2007). The role of the internal auditor in risk management in the Jordanian commercial banks, Annual Scientific Conference of the Seventh International, risk management and the knowledge economy, the eighth axis: risk management and auditing, Faculty of Economics and Administrative Sciences, Zaytoonah University, Amman, Jordan, 3.

Kamit, L. Wilson. (2008). Role of Internal Auditors in the Bank and Supervised institutions. Bank for International Settlement Review, 89.

Kinney, J., \& William, R. (2003). Auditing Risk Assessment and Risk Management Processes, as cited in Research Opportunities in Internal Auditing, The Institute of Internal Auditors Research Foundation, Florida USA, 141.

Mclemore, IVY. (1999). Best Practices in Internal Audit, Business Finance (Formerly Controller Magazine), November, 67.

McNamee, D. (2000). Targeting Business Risk. Internal Audit, 57(5), 248.

Ministry of Finance. (2010).Finance Minister's decision no. 93 dated 17/3/2010, the website of the Ministry of Finance: www.syriafinance.org. 
Ministry of Finance. (2010). Finance Minister's decision no. 94 dated 17/3/2010, the website of the Ministry of Finance: www.syriafinance.org.

Miqdad, Omar Youssef Mohammed. (2002).Professionalism of internal auditors in Jordanian banks and their relationship to the outputs of work, Master in Accounting, Yarmouk University, Irbid, Jordan.

Monetary and Credit Council in Syria. (2009). Corporate Governance in conventional banks operating in the Syrian Arab Republic, the Central Bank of Syria, 1.

Obeirat, Mugadam, \& Nagaz, Ahmed. (2007). Internal audit as an effective tool in decision-making. Journal of Arab Open Academy in Denmark, second edition.

Pickett, S. K. (2003). The Internal Auditing Handbook, $2^{\text {nd }}$ ed., John Wiley Inc. UK, 2003.

Prawitt, Douglas F. (2003). Managing the Internal Audit Function, the Institute of Internal Auditors Research Foundation, Florida USA, 134.

Public Company Accounting Oversight Board (PCAOB). (2004). An Audit of Internal Control over Financial Reporting Performed in Conjunction with an Audit of Financial Statements, Auditing Standard No. 2.

Securities Commission and the Syrian financial markets. (2008). Resolution no. 18/2008, the Authority's website: www.scfms.sy.

Standards for the Professional Practices Framework. (1999), Side IIA: www.theiia@org.

The Central Bank of Syria. (2002). Instructions for the requirements of internal audit in banks, Central Bank of Syria's decision no. (123 / M N / B 4) for the year.

The Central Bank of Syria. (2010). Sixth Annual Forum for compliance managers, the website of the Central Bank of Syria: www.banquecentrale.gov.sy.

The Institute of Internal Auditors IIA. (2004). The Role of Internal Auditing in Enterprise-Wide Risk Management, IIA, Florida, Sep. www.theiia.org

The Institute of Internal Auditors, IIA, Standards for the Professional Practices Framework. (2003). Florida, 2.

Treasury, H.M. (2004). Management of Risk- Principals and Concepts. The Orange Book-Revised Version, UK, 7, 8. 